\title{
CLINICAL AND EX.PERIMENTAL STUDIES ON SODIUM BENZOATE
}

\author{
The Value of the Sodium Benzoate Test of Renal Function, and \\ THE EFFect of INJURy OF THE LIVER ON HipPURIC \\ Acid Synthesis ${ }^{1}$ \\ BY ALBERT W. BRYAN \\ From The Mayo Foundation, Rochester, Minnesota
}

(Received for publication February 26, 1925)

\section{INTRODUCTION}

These studies were undertaken in order to determine the clinical value of the sodium benzoate test of renal function as proposed by Kingsbury and Swanson (27).

Hippuric acid has claimed the attention of physiologic chemists and pathologists for many years (40). The basis of this interest lies in the generally accepted fact of its formation in the body by the conjugation of benzoic acid, or its salts, with glycocoll, resulting in the detoxication of the former and the loss of the latter to the body. The question as to where this conjugation takes place and whence comes the large amount of requisite glycocoll still claims the attention of the chemist. The interest of the pathologist is due to the celebrated experiments of Bunge and Schmiedeberg (8), who, in 1877, perfused the kidneys of surviving dogs with benzoic acid and glycocoll, and later found hippuric acid in the transfused blood, from which they concluded that, at least in the dog, the kidney is the site of the synthesis. For many years their results stood unchallenged. If correct, this function of the kidney is singular since other substances synthesized by the body appear in the various organs, but are only excreted by the kidney. The possible aberration of this synthesizing

${ }_{1}$ This work was done under the direction of Dr. L. G. Rowntree, of the Division of Medicine, Mayo Clinic. 
ability in the case of diseased kidneys is the basis of numerous attempts to employ it as a test of renal function.

The employment of sodium benzoate in determining renal function is not new. As early as 1879 Jaarsvald and Stokvis (22) studied a number of cases with various types of renal complaints. They concluded that in man the synthesis of hippuric acid is diminished or entirely absent in.affections of the kidney, more especially in parenchymatous nephritis. In 1880 Weyl and Anrep (50), and in 1883, Kronecker (28) carried on rather similar work with somewhat contradictory results. Kingsbury has explained these by the fact that with their method some of the hippuric acid was hydrolyzed to benzoic acid by alkali. More recently Violle (49) has reported that in nephretic patients, after giving $0.5 \mathrm{gm}$. doses of sodium benzoate, the excretion of hippuric acid is much less than in normal persons.

Kingsbury and Swanson (26) perfected and simplified the method of hippuric acid determination, and also administered sodium benzoate in $2.4 \mathrm{gm}$. doses to many normal and abnormal persons. Their results, working with approximately normal university students, are of particular value in indicating what the average rate of synthesis should be in normal persons.

Morgulis, Pratt, and Jahr (39) carried on a somewhat parallel investigation giving particular attention to the rôle of the free benzoic acid excreted. They raised the question as to whether there was sufficient of this substance to vitiate the use of the test clinically. This was at variance with Kingsbury (25), who was able to find only traces of free benzoic acid when accidental hydrolysis had been prevented.

Snapper and his co-workers $(45,46,47,48)$ have recently reported interesting and significant work in which they not only amplified the work of Bunge and Schmiedeberg and also Kingsbury and Bell (24), but have made a number of clinical observations as well.

The earlier portion of this study, especially that dealing with pregnant and postpartum women, was carried on in one of the smaller outlying hospitals of Minneapolis, and the data, while essentially correct, are less complete than those of more recent study. Most of the work was conducted at the Mayo Clinic where it was possible to make parallel studies of the various functions. 


\section{MECHANISM OF THE SYNTHESIS}

The following facts concerning the mechanism of hippuric acid synthesis seem well supported. Hippuric acid (18) is one of the nitrogenous end-products of protein metabolism and is a combination product arising by the union of glycocoll and benzoic acid.

The benzoic acid component arises from one of two sources, etc. (18): either from aromatic products of vegetable food, as cinamic acid, quinic acid, and so forth, which in metabolism are catabolized to benzoic acid, or from phenylalanin, which undergoes complete dissociation in normal metabolism. The phenylpropionic acid which is produced from this in intestinal putrefaction is oxidized freely into benzoic acid when resorbed (3).

The origin of the glycocoll component is, however, far more complicated. In carnivorous animals, Brugsch and Hirsch (6) (7) found that the degree of hippuric acid formation after the introduction of benzoic acid was lower than in the herbivorous animal, that the amount of free benzoic acid was greater than that paired with glycocoll, and that in the dog detoxication of benzoic acid occurs only in relatively small part by the formation of hippuric acid and to a considerable extent by the formation of reducing substances (glycuronates).

Schmiedeberg (44) suggested that the synthesis took place under the influence of a ferment "histozyme."

In human beings Lewinski (31) found that after the administration of benzoic acid the only mode of hippuric acid formation was by hydrolytic protein cleavage. From his work he concluded that a person on a diet rich in proteins can transform more benzoic acid to hippuric acid than otherwise, and that the appearance of reducing substances in the urine is an expression of the impoverishment of the organism in glycocoll.

Magnus-Levy (36), Wiechowski (51), Ringer (41), Abderhalden (1), and Delprat and Whipple (14), found that when benzoic acid was given to herbivora in quantity, the animal excreted one-third or more of the total nitrogen as hippuric acid. Ringer suggested that the large quantities of glycocoll might originate from the "extra-destroyed" protein, and not from protein that would have been metabolized had no benzoate been given.

Epstein and Bookman (16), found no "reserve" glycocoll in the animal body. They considered the production of glycocoll dependent upon the amount of benzoic acid present in the circulation, and that the processes involved might represent either destruction of higher amino-acids or construction from simpler bodies.

The results of Lewis $(33,34)$, and of McCollum and Hoagland (35) were essentially consistent. Lewis concluded that the decreased excretion of uric acid must be regarded as the result of decreased uric acid formation due to the lowering of the level of nuclear metabolism, and as an example of specific influence on nuclear metabolism rather than on general endogenous metabolism. Sodium hippurate failed to produce changes in either creatinin or uric acid elimination, and hence he concluded that the effect was due to the action of free benzoic acid and not to conjugated, non-toxic hippuric acid. 
Whipple (14) proposed the hypothesis that the increase in urinary nitrogen is due to the lack of available glycocoll, and that under these conditions a demand for the drug being very acute, the body protein is broken down to supply the "emergency requirement." Parker and Lusk considered the possibility of a "glycocoll reserve" which can be washed out by successive doses of benzoate.

Cohn (9) (10) noted that feeding proteins and their glycocoll yielding decomposition products, counteracted the toxic effect of benzoic acid in rabbits. In contrast with Wiener (52), however, he failed to note detoxification of the benzoic acid when leucin was given. Friedmann and Tachau (17), and Hoffmann (21) were unable to demonstrate that amino, hydroxy, or fatty acids were precursors of glycocoll.

Among the most recent investigators of the origin of glycocoll are Griffith and Lewis (19) (20). In their work with rabbits they noted that the rate of excretion of hippuric acid was notably increased by the administration of glycocoll with the sodium benzoate. This, they concluded, probably represented an increased rate of synthesis due to the presence in the organism of large amounts of preformed glycocoll. Their later work shows that the synthesis in rabbits is enhanced by feeding protein rich in glycocoll with the sodium benzoate, although it is not enhanced by feeding other proteins, unless glycocoll is also fed. 'From these facts they consider it improbable that the ordinary reactions of protein metabolism produce readily available precursors of glycocoll.

Csonka (11) (12) does not doubt the synthetic production of glycocoll in the normal animal. Experimenting with swine he found that under the influence of benzoic acid certain reducing substances (glycuronates) were eliminated in the urine. The quantity of these was largest when casein was given, and smallest when gelatin was given, pointing to the inverse relation to the preformed glycocoll content of the protein ingested. In his opinion, there is an increased nitrogen elimination when benzoic acid is administered, which supports the claim that the metabolism rises after its ingestion.

As to the amount of sodium benzoate which a human being is able to convert, Lewinski (31) found that a man could completely convert $20 \mathrm{gm}$. of benzoic acid ingested within twelve hours without ill effect, and on a diet rich in glycocoll 40 gm. of benzoic acid, of which only 10 per cent was excreted in the free state. Lewis (33) gave men doses of from 6 to $10 \mathrm{gm}$. of sodium benzoate of which 85 or 90 per cent was eliminated in five or six hours as hippuric acid. Dakin (13) found that sodium benzoate taken by human beings in 5 to $10 \mathrm{gm}$. doses for two or three days is completely converted into hippuric acid and is eliminated as such in the urine, no free benzoic acid being excreted under these conditions.

Particular points to be gleaned from the foregoing are: (1) normal human beings may completely convert at least $25 \mathrm{gm}$. of sodium benzoate to hippuric acid without ill effect and with the appearance of only traces of free benzoic acid in the urine. When larger amounts of benzoic acid or its salts are given, the lamount converted is greater if there is extra available glycocoll in the body, and (2) the results of many investigations point to two available sources for the origin of 
glycocoll in hippuric acid formation: synthesis and preformed glycocoll; the latter includes glycocoll liberated by the catabolism of body protein and that present in food protein.

\section{SITE OF THE SYNTHESIS}

Important as the foregoing considerations are to a proper understanding of benzoic acid detoxication, it is even more essential to decide whether the synthesis takes place in the kidney only, or also in some other organ, such as the liver.

As early as 1857 Kühne and Hallwachs (29) concluded that the formation of hippuric acid from introduced benzoic acid did not occur in the intestines, nor in the circulating blood, but in the hepatic vessels in the presence of the constituents of bile (glycocholic acid). This was supported by Rosenberg (43), and by Lewis (32) in his more recent experiment in which he inserted a cannula in the common bile duct of a rabbit and demonstrated that in this animal synthesis of hippuric acid occurred after exclusion of bile from the intestine.

The perfusion experiments of Bunge and Schmiedeberg (8) have already been referred to. Their results were confirmed by Kochs (27), who noted that synthesis took place even in the comminuted kidney of the dog, ox, and calf; also by Bashford and Cramer (2) who determined hippuric acid crystals in renal tissue and blood which had been triturated until the microscope showed no intact cells, and concluded that the formation of the hippuric acid was not dependent on intact and living cells.

In 1911, Friedmann and Tachau (17) experimenting with rabbit livers concluded that, at least in herbivora, the liver partook in the synthesis. Except for this, the results of Bunge and Schmiedeberg (8) were practically unchallenged until Kingsbury and Bell (24) found hippuric acid in the tissues of nephrectomized dogs after injections of glycocoll and sodium benzoate, and concluded that in the dog the kidney was not the only organ which synthesized hippuric acid.

Lackner, Levinson and Morse (30) believed that in the dog the excretion of hippuric acid varied with the condition of the liver, the condition of the kidney remaining constant, and that if the liver partook in this synthesis to any great extent, pathologic involvement of the liver should be recognizable by this means. Some experimental and clinical evidence was found in support of this claim.

Delprat and Whipple (14), working with dogs with necrosis of the liver induced by chloroform, concluded that in this condition the synthesis was not prevented but was distinctly delayed; also that the liver normally partakes in this action, but that other cell protoplasm may partake in the reaction.

Morgulis (39) and his co-workers believed that extensive injury to the liver was responsible for the failure of certain preliminary steps in the process, namely, the formation of glycocoll, rather than that it indicated an actual participation of the liver in the synthesis.

Snapper, Grünbaum and Neuberg (48) believed that Kingsbury and Bell (24) based their conclusions on too little evidence. Accordingly they repeated the 
work of Bunge and Schmiedeberg (8), and also that of Kingsbury and Bell (24). They were thus able to conclude, in confirmation of the earlier work of Bunge and Schmiedeberg, and in opposition to that of Kingsbury and Bell that not only is hippuric acid synthesized locally in the kidney of a dog, but that in this animal this synthesis occurs only in the kidney.

Their further work with swine and sheep (48) is of interest in this connection. It was also their privilege to perfuse two human kidneys (48) with fair remaining function, immediately'after removal, one being from a patient with renal tuberculosis and the other from a patient with tumor of the kidney. In each instance they were able to demonstrate definite amounts of hippuric acid in the perfusion blood to which sodium benzoate and glycocoll had been added. From their extensive work they concluded (1) that in the perfusion of the kidneys of dogs, swine, and sheep with benzoic acid and glycocoll, hippuric acid is synthesized, and (2) that this also occurs in the isolated human kidney.

Brakefield and Schmidt (5) found that in two rabbits whose bile ducts had been ligated only 40 per cent of the amount of hippuric acid synthesized by normal rabbits was excreted; they also observed that normal dogs able to conjugate 95 per cent of a given amount of benzoate, conjugated only 60 per cent after ligation of the common bile duct.

Kingsbury and Bell (23) worked with rabbits made nephritic with racemic tartaric acid. They concluded that if hippuric acid was synthesized in the kidney of the rabbit, it must be accomplished either by the degeneration cells of the convoluted tubules, or by the cells of the glomeruli. The latter possibility is supported by our own work; that is, in the cases of nephrosis in which the glomeruli were but little impaired, the elimination of hippuric acid was but little reduced; it was greatly reduced in cases of nephritis or of other destructive renal lesions.

Morgulis (39) regards the kidney as the essential organ of hippuric acid synthesis, but finds the amount of free benzoic acid to be increased in cases of nephritic disease. Kingsbury (25), however, believes that sodium benzoate is completely converted and eliminated as hippuric acid in individuals whose kidneys have been extensively damaged; he also believes that the synthesis of the product must be as rapid as its excretion. This is in harmony with the work of Snapper and Grünbaum (47), who found that patients with renal insufficiency synthesized sodium benzoate to hippuric acid which, however, is dammed back in the blood stream.

Reviewing the literature which we have thus briefly cited, it appears certain that whenever the requisite glycocoll and benzoic acid are available to it, the kidney is the main site of the synthesis of hippuric acid. This is shown by the work of Bunge and Schmiedeberg (8), questioned by Friedmann and Tachau (17), and by Kingsbury and Bell (24), but confirmed by Kochs (27), Bashford and Cramer (2), Snapper, Grünbaum, and Neuberg (45-48 inclusive), as well as by our own work in various cases of nephritic lesions in which the elimination of hippuric acid seemed quite proportional to the extent of the renal damage. It appears equally true that the kidney cannot perform this function satisfactorily if the liver does not function properly. Morgulis' (39) conception of the liver as 
playing an important although a secondary rôle, is supported by the work of Delprat and Whipple (14), by Lackner, Levinson, and Morse (30), by Brakefield and Schmidt (5), and also by us in our work upon human cases with damaged livers. That this rôle is distinctly secondary is most strikingly shown by our finding that a completely hepatectomized dog can synthesize appreciable amounts of hippuric acid, and by Bashford and Cramer (2), who many years ago demonstrated the synthesis of hippuric acid in vitro by macerated renal tissue.

\section{METHODS}

Administration of the sodium benzoate. Many of the patients in the hospital were studied according to a routine which was designed to show the total elimination of hippuric benzoic acid for the twenty-four hours preceding the three-hour test, as well as for the twenty-one hours following it. It seemed that a more adequate idea would thus be obtained of the usual hippuric and benzoic acid output, as well as some control on the subject's reaction to the test.

Regime in the management of the test. In the ordinary clinical application of the test the following procedure might be followed:

Fruits are omitted from the diet for at least twenty-four hours preceding the test. Just before starting the test the patient is asked to void and this specimen is discarded. The sodium benzoate is then dissolved in its container in $100 \mathrm{cc}$. of water and drunk; the container is rinsed with $200 \mathrm{cc}$. of water which is also drunk; an hour later another $200 \mathrm{cc}$. of water is taken.

Specimens are collected at the end of the second hour and at the end of the third hour and these two specimens are analyzed for hippuric acid by the methods of Kingsbury and Swanson (26).

Breakfast is withheld until after the third-hour specimen is voided.

The value of the test being once established, the "before" and "after" periods mentioned above, as well as the free benzoic acid determinations might be dispensed with. The essential information which the test may be expected to furnish may then be obtained from the two-hour and three-hour determinations, or, if the deductions from the tables which follow are correct, from the results of the twohour specimen alone. If this cannot be established the test is probably too cumbersome for any clinical application. The dietary restriction in fruits is probably necessary since benzoic acid occurs in fruits, particularly in cranberries.

Each of the fifty-two patients in this series received $2.4 \mathrm{gm}$. of sodium benzoate by mouth, as described, the amount originally employed by Kingsbury. It is equivalent to $2.0 \mathrm{gm}$. of benzoic acid, in percentage terms of which the results of the test are calculated. Thus, if a patient excretes $1.5 \mathrm{gm}$. of benzoic acid, the portion of the original dose excreted may be considered as 75 per cent. More recently Kingsbury has advocated giving $1.8 \mathrm{gm}$. of sodium benzoate for each square meter of body surface, as determined by the height and weight formula of $\mathrm{Du}$ Bois (15). This would be, for the average adult, essentially the amount used in this study. Therefore, it appears that in considering the power of the kidneys 
of the average adult to detoxicate benzoic acid the observation of this refinement would not greatly alter the results obtained. In none of the tables was the excreted hippuric acid expressed as such, but always for the sake of simplicity, in the terms of benzoic acid. The relations of hippuric to benzoic acid may be readily seen from their molecular weights, 179 and 122 respectively; the foregoing dosage, then, would be equivalent to $2.93 \mathrm{gm}$. of hippuric acid.

Total benzoic acid. The method employed in this analysis was the same as that described by Kingsbury and Swanson (26), except that only half the amounts mentioned in the reference were employed; this modification was later adopted by Kingsbury himself. Since the application of this method required the removal of protein from the urine when present, as in some of the nephritic cases, this also was done by the method described by Kingsbury and Swanson. The specimens were preserved by the use of 2 per cent nitric acid and a small amount of 10 per cent thymol in chloroform. Frequent duplicate determinations were made throughout the work. The chloroform was washed, as described.

Free benzaic acid. This was determined, as described by Morgulis (39) and his co-workers, except that it was not always possible to employ $100 \mathrm{cc}$. samples of. urine. To quote the details:

"For the purpose of deproteinizing, sodium hydroxide was added until the strongly acid urine reacted just faintly acid to litmus. Then $0.5 \mathrm{gm}$. of tannic acid was added to every $100 \mathrm{cc}$. of urine. A flocculent precipitate was formed in the presence of albumin, which was filtered off after the mixture had been allowed to stand for a few minutes. . . . . O Of the deproteinized urine $100 \mathrm{cc}$. samples were immediately measured out into separatory funnels and saturated.with ammonium sulphate. The mixture was then strongly acidified by the addition of $1 \mathrm{cc}$. of concentrated nitric acid and extracted with four portions of freshly washed chloroform."

\section{PRESENTATION OF CASES}

The fifty-two cases in the series may be considered in five groups: (1) normal subjects, (2) pregnant and postpartum subjects, (3) subjects with essential renal involvement, (4) subjects with only slight renal involvement, (5) those with definite hepatic involvement. Certain experiments with dogs are also considered in connection with those in the latter group.

With the exception of tables 2, 3, and 4, the tables were arranged according to the value of the two-hour benzoate excretion, rather than the third-hour value, since the former seems to be more significant in indicating renal impairment. This belief is based on the observation that there is a tendency for the third-hour value so to raise the value for the whole three hours that it may approximate the 
normal ( 85 to 90 per cent), even though the two-hour value is notably decreased. Hence, at the end of the three hours the significance of the test might be concealed if it were based on this value alone.

Group 1. Normal subjects. In interpreting results it is presumed that the standards set by Kingsbury are approximately correct. After experimenting with many normal university students, as well as a number of cardiac and nephritic patients, he concluded that 70 per cent or more of the initial dose (2.4 gm.), expressed as benzoic acid, is excreted in the first two-hour period, and a total of 90 per cent or more is excreted during the entire three-hour period of the test. Recently he has said "at least 80 per cent of the hippuric acid theoretically equivalent to the ingested dose of benzoate should be found in the three-hour specimen. Sixty-seven tests made on normal medical students in this laboratory (University of Minnesota), showed an output of 80 per cent or above, 91 per cent of these sixty-seven cases showed benzoate tests above 85 per cent." The results of the tests in thirteen cases are well within the limits just outlined (table 1). This is true for the blood urea and the phenolsulphonephthalein, as well as for the sodium benzoate test. The three-hour value in two of the cases seems to be above 100 per cent; this is possible when the excretory power of the kidney is high and when the diet may not have been adequately controlled. Under such conditions the benzoate available from sources other than the dose given must be considerable, assuming the technic to have been faultless otherwise. This fact does not appear to militate against the value of the test since in cases in which the excretory power of the kidney is reduced, the excretion seems to proceed at a lower but maximal figure maintained for a longer time.

The subjects of this group, while not strictly normal, gave but little evidence of renal damage. The values found bear out those established by Kingsbury as being approximately correct.

Group 2. Pregnant and postpartum subjects. The subjects of this group had had infections of various types which apparently affected the kidneys, and all of these infections seem to have been reflected in the results of the renal tests.

The rôle of infection in the etiology of the nephritides is a matter of common medical knowledge, and the effect of infection on the 
ability of the kidney to excrete hippuric acid has been previously noted. The correctness of these observations seems well shown by a comparison of table 2 , composed of cases with normal or nearly normal values for the benzoate test, with table 3 , composed of cases with definitely abnormal values.

TABLE 1

Normal renal function

\begin{tabular}{|c|c|c|c|c|c|c|c|c|c|}
\hline \multirow[b]{2}{*}{ ฮٌ } & \multicolumn{2}{|c|}{$\begin{array}{l}\text { Milligrams for } \\
\text { each } 100 \mathrm{cc} .\end{array}$} & \multirow[b]{2}{*}{ 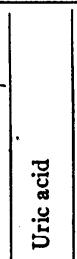 } & \multirow{2}{*}{ 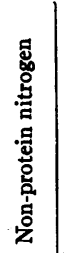 } & \multirow{2}{*}{ 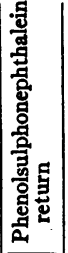 } & \multicolumn{3}{|c|}{$\begin{array}{c}\text { Sodium benzoate } \\
\text { return }\end{array}$} & \multirow[b]{2}{*}{ Diagnosis } \\
\hline & 芯 & 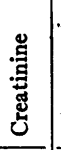 & & & & 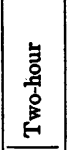 & 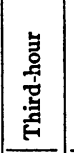 & ङ્ّ̆ & \\
\hline \multirow[t]{2}{*}{78} & & & $\begin{array}{c}\text { per } \\
\text { cent }\end{array}$ & $\begin{array}{l}\text { per } \\
\text { cent }\end{array}$ & $\overline{\substack{\text { per } \\
\text { cent }}}$ & 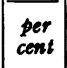 & $\mid \begin{array}{c}\text { per } \\
\text { cent }\end{array}$ & $\begin{array}{l}\text { per } \\
\text { cent }\end{array}$ & \\
\hline & Normal & & & & & 70.0 & 20.0 & 90.0 & \\
\hline 1 & 32 & 1.7 & 3.7 & & 65 & 68.1 & 19.3 & 87.5 & Malignant hypertension \\
\hline 2 & 38 & 1.3 & & 38.0 & 80 & 70.4 & 17.7 & 88.1 & Exophthalmic goiter \\
\hline 3 & & & $1 \cdots$ & & & 72.0 & 12.0 & 84.0 & Normal? Hemorrhagic icterus \\
\hline 4 & & & & & & 72.0 & $32.0 \mid$ & 104.0 & Normal pregnancy \\
\hline 5 & 53 & 1.3 & 2.4 & & 55 & 72.0 & 12.4 & 84.6 & $\begin{array}{l}\text { Adenomatous thyroid; diseased } \\
\text { gallbladder }\end{array}$ \\
\hline 6 , & & & & & 70. & 73.6 & 21.8 & 95.5 & $\begin{array}{l}\text { Exopthalmic goiter; pregnancy, } \\
\text { three months }\end{array}$ \\
\hline 7 & 34 & 1.7 & 3.5 & & 30 & 74.8 & 13.6 & 88.5 & Adenoma of thyroid \\
\hline 8 & 34 & 1.6 & & 40 & 65 & 77.9 & 11.9 & 89.0 & Carcinoma of adrenal \\
\hline 9 & 36 & 1.4 & & 38 & 80 & 78.4 & 17.9 & 96.3 & $\begin{array}{l}\text { Exophthalmic goiter; myocardial } \\
\text { degeneration }\end{array}$ \\
\hline 10 & & & & & 58 & 81.4 & 17.3 & 98.7 & Normal puerperium \\
\hline 11 & 44 & & & & 44 & 81.9 & 24.0 & 106.0 & Normal pregnancy \\
\hline 12 & 34 & 1.7 & 3.5 & & 60 & 82.5 & 14.5 & 97.0 & Adenomatous thyroid; myocardial \\
\hline 13 & $\therefore$ & & & & & 86.0 & 11.0 & 97.0 & $\begin{array}{l}\text { degeneration } \\
\text { Normal puerperium }\end{array}$ \\
\hline \multicolumn{3}{|c|}{ Group average. } & & & 58. & 74.7 & 17.3 & 92.0 & \\
\hline
\end{tabular}

It may be noted that all cases in which there was a history of scarlet fever and rheumatism, and cases in which chronic tonsillitis had occurred, as well as many cases of pyhorrhea and of six cases of gonorrheal infection are included in table 3. With few exceptions the results of phenolsulphonephthalein and the sodium benzoate tests average higher in table 2 than in table 3 . This difference, however, 
TABLE 2

Normal cases

\begin{tabular}{|c|c|c|c|c|c|c|}
\hline \multirow[b]{2}{*}{ छ } & \multirow[b]{2}{*}{ Infection } & \multirow[b]{2}{*}{ Time } & \multirow{2}{*}{ 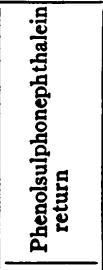 } & \multicolumn{3}{|c|}{ Sodium benzoate return } \\
\hline & & & & 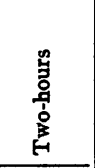 & 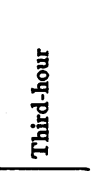 & క్ర \\
\hline \multirow{4}{*}{2} & & & per cent & per cent & per cont & per cent \\
\hline & $\begin{array}{l}\text { Measles } \\
\text { Influenza }\end{array}$ & $\begin{array}{l}1912 \\
1918\end{array}$ & 40 & $\begin{array}{c}105 \\
(89)\end{array}$ & $\begin{array}{l}15.5 \\
(15)\end{array}$ & $\begin{array}{c}121 \\
(104) ?\end{array}$ \\
\hline & Gonorrhea & 1922 & & 74 & 15 & 89 \\
\hline & Postpartum* & 7 weeks & & & & \\
\hline \multirow[t]{2}{*}{3} & $\begin{array}{l}\text { Diseases of childhood } \\
\text { Appendectomy }\end{array}$ & & & 86 & 11 & 97 \\
\hline & Postpartum* & 4 days & & & & \\
\hline \multirow[t]{3}{*}{4} & Diseases of childhood & & & & & \\
\hline & $\begin{array}{l}\text { Influenza } \\
\text { Tonsillitis }\end{array}$ & At 13 years & 58 & 81 & 17 & 98 \\
\hline & Postpartum & 4 days & & & & \\
\hline \multirow[t]{2}{*}{7} & Mumps in childhood (?) & & & & & \\
\hline & $\begin{array}{l}\text { Tonsillectomy } \\
\text { Pregnancy }\end{array}$ & $\begin{array}{l}\text { At } 13 \text { years } \\
8 \text { months }\end{array}$ & 44 & 82 & 24 & 106 \\
\hline \multirow[t]{3}{*}{$14^{\circ}$} & $\begin{array}{l}\text { In hospital on account of } \\
\text { eyes }\end{array}$ & Until 9 years & & & & \\
\hline & $\begin{array}{l}\text { Influenza } \\
\text { Hereditary syphilis (?) }\end{array}$ & 1918 & & 72 & 32 & 104 \\
\hline & Pregnancy & 5 months & & & & \\
\hline 8 & $\begin{array}{l}\text { Diseases of childhood } \\
\text { Pregnancy }\end{array}$ & 7 months & 55 & 48 & 46 & 94 \\
\hline \multirow[t]{2}{*}{20} & $\begin{array}{l}\text { Diseases of childhood } \\
\text { Tonsillitis }\end{array}$ & 1914 & 50 & 64 & 31 & 05 \\
\hline & $\begin{array}{l}\text { Influenza } \\
\text { Pregnancy }\end{array}$ & $\begin{array}{c}1918 \\
8 \text { months }\end{array}$ & & & & \\
\hline \multicolumn{3}{|c|}{ Average of 7 practically normal cases. } & 49 & 75 & 25 & 100 \\
\hline
\end{tabular}

* Sodium benzoate test. 
TABLE 3

Abnormal cases

\begin{tabular}{|c|c|c|c|c|c|c|}
\hline \multirow[b]{2}{*}{ 气̆ } & \multirow[b]{2}{*}{ Infection } & \multirow[b]{2}{*}{ Time } & \multirow{2}{*}{ 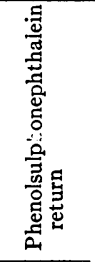 } & \multicolumn{3}{|c|}{ Sodium benzoate return } \\
\hline & & & & 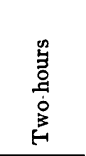 & 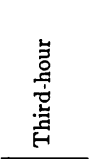 & స్ّ \\
\hline \multirow{3}{*}{1} & & & per cent & per cent & per cent & per cent \\
\hline & $\begin{array}{l}\text { Recent puerperal fever } \\
\text { Postpartum* }\end{array}$ & 2 weeks & 43 & $\begin{array}{c}25 \\
(44)\end{array}$ & $\begin{array}{c}47 \\
(27)\end{array}$ & $\begin{array}{c}72 \\
(71)\end{array}$ \\
\hline & Postpartum* & 3.5 weeks & & 62 & 7 & 69 \\
\hline \multirow[t]{2}{*}{5} & $\begin{array}{l}\text { Diseases of childhood } \\
\text { Influenza }\end{array}$ & 1918 & $\begin{array}{c}20 \\
(31)\end{array}$ & 48 & 27 & 75 \\
\hline & $\begin{array}{l}\text { Appendectomy } \\
\text { Gonorrhea } \\
\text { Term pregnancy* }\end{array}$ & & 42 & & & \\
\hline \multirow[t]{4}{*}{9} & $\begin{array}{l}\text { Diseases of childhood } \\
\text { Tonsillitis }\end{array}$ & & 40 & $\begin{array}{c}37 \\
(54)\end{array}$ & $\begin{array}{c}15 \\
(14)\end{array}$ & $\begin{array}{c}52 \\
(68)\end{array}$ \\
\hline & "Rheumatism" & & & 71 & 13 & 84 \\
\hline & Pregnancy & 7.5 months & & & & \\
\hline & Pregnancy & 8 months & & & & \\
\hline \multirow[t]{3}{*}{10} & Appendectomy & 1914 & 58 & 43 & 20 & 63 \\
\hline & Term pregnancy & & & (53) & (22) & $(75)$ \\
\hline & Postpartum & 1 month & & 63 & 24 & 87 \\
\hline \multirow[t]{6}{*}{11} & Pneumonia & At 11 years & & 42 & 17 & 59 \\
\hline & Influenza & 1918 & 43 & (47) & $(13.5)$ & $(61.5)$ \\
\hline & Thyroidectomy & At 17 years & & 52 & 10 & 62 \\
\hline & Gonorrhea & & & & & \\
\hline & Pregnancy & 8.5 months & & & & \\
\hline & Postpartum & 2 weeks & & & & \\
\hline \multirow[t]{4}{*}{12} & Measles & 1920 & & & & \\
\hline & Scarlet fever & & 29 & 39 & 29 & 68 \\
\hline & $\begin{array}{l}\text { Appendectomy } \\
\text { Gonorrhea }\end{array}$ & 1917 & & & & \\
\hline & $\begin{array}{l}\text { Gonorrnea } \\
\text { Pregnancy }\end{array}$ & 8 months & & & & \\
\hline \multirow[t]{3}{*}{13.} & Diseases of childhood & & & & & \\
\hline & $\begin{array}{l}\text { Scarlet fever } \\
\text { Gonorrhea }\end{array}$ & & 45 & 50 & 24 & 74 \\
\hline & Pregnancy & 8 months & & & & \\
\hline
\end{tabular}

* Sodium benzoate test. 
TABLE 3-Continued

\begin{tabular}{|c|c|c|c|c|c|c|}
\hline \multirow[b]{2}{*}{ 总 } & \multirow[b]{2}{*}{ Infection } & \multirow[b]{2}{*}{ Time } & \multirow{2}{*}{ 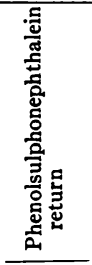 } & \multicolumn{3}{|c|}{ Sodium benzoate return } \\
\hline & & & & 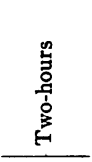 & 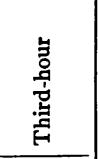 & 㞼 \\
\hline & & & per cent & per cent & per cent & per cent \\
\hline \multirow[t]{2}{*}{15} & $\begin{array}{l}\text { Diseases of childhood } \\
\text { Measles }\end{array}$ & & & & & \\
\hline & $\begin{array}{l}\text { Pneumonia } \\
\text { Tonsillectomy } \\
\text { Pregnancy }\end{array}$ & $\begin{array}{l}\text { At } 6 \text { years } \\
1921 \\
8.5 \text { months }\end{array}$ & 43 & 53 & 30 & 83 \\
\hline 16 & $\begin{array}{l}\text { "Rheumatism"; measles } \\
\text { Tonsillitis } \\
\text { Term pregnancy }\end{array}$ & & 53 & 57 & 27 & 84 \\
\hline 17 & $\begin{array}{l}\text { Diseases of childhood } \\
\text { Scarlet fever; appendectomy } \\
\text { Tonsillitis } \\
\text { Pregnancy }\end{array}$ & $\begin{array}{c}1921-22 \\
6 \text { months }\end{array}$ & 55 & 42 & 28 & 70 \\
\hline 19 & $\begin{array}{l}\text { Acute rheumatism } \\
\text { Torsillectomy } \\
\text { Term pregnancy }\end{array}$ & 1921 & 27 & 64 & 22 & 86 \\
\hline 18 & $\begin{array}{l}\text { Mumps } \\
\text { Carbuncles } \\
\text { Influenza } \\
\text { "Toxemia of pregnancy" } \\
\text { glycosuria } \\
\text { Pregnancy }\end{array}$ & $\begin{array}{l}\text { At } 12 \text { years } \\
1916 \\
1918 \\
7 \text { months }\end{array}$ & 60 & 40 & $58 ?$ & $98 ?$ \\
\hline \multicolumn{3}{|c|}{ Average of abnormal cases. } & 44 & 49 & 27 & 76 \\
\hline
\end{tabular}

is considerably more definite in the benzoate than in the phenolsulphonephthalein reactions. Grouping these cases according to their pregnant and postpartum condition gives no characteristic difference. In such a small series of cases with so many factors to consider, the effect of the pregnant state itself on the renal function as revealed by these tests, is of course open to speculation.

Group 3. Subjects with essential renal involvement. In table 5 is presented a group of fifteen patients, all of whom show more or less 
albumin and elevation, or recent history of elevation, of the blood urea at the time of the benzoate test. In four patients the blood urea was more than $100 \mathrm{mg}$. for each $100 \mathrm{cc}$. of blood and in one of these more than 300. All show considerable depression in the benzoate return, the highest three-hour return being 50 per cent instead of the normal 70 per cent. The eight patients showing most marked impairment (cases 1, 2, 3, 4, 5, 6, 8, and 9) also show a very marked and parallel depression of the reactions to both the phenolsulphone-

TABLE 4

Cases of pregnant and postpartum women (summary)

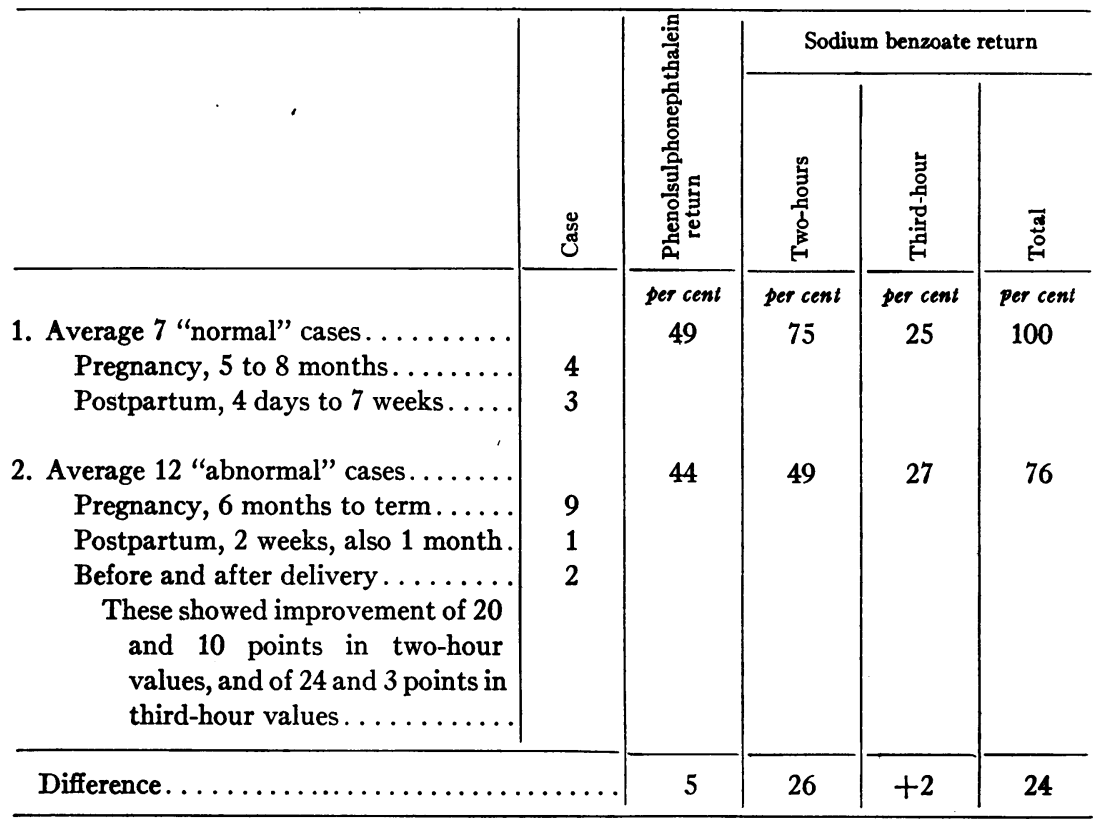

phthalein and sodium benzoate test. The highest value for the former was 35 per cent, most of them being 25,20 , or lower, many even indicating no return. The highest two-hour benzoate return was 30 per cent, while the lowest reached the extremely low, yet definite amount of 4.3 per cent, or almost complete retention.

Of five patients (cases 7, 10,11,12, and 15) in this group having phenolsulphonephthalein values above 40 per cent, or within the normal limits of that test, four (cases 7, 10,12, and 15) had more or 
TABLE 5

Cases of rather marked renal lesions

\begin{tabular}{|c|c|c|c|c|c|c|c|c|c|}
\hline \multirow[b]{2}{*}{$\underline{g}$} & \multicolumn{2}{|c|}{$\begin{array}{l}\text { Milligrams for } \\
\text { each } 100 \text { cc. }\end{array}$} & \multirow[b]{2}{*}{ 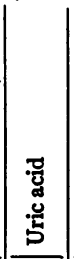 } & \multirow{2}{*}{ 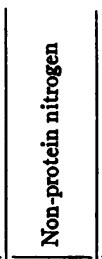 } & \multirow{2}{*}{ 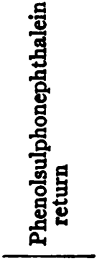 } & \multicolumn{3}{|c|}{$\begin{array}{c}\text { Sodium benzoate } \\
\text { return }\end{array}$} & \multirow[b]{2}{*}{ Diagnosis } \\
\hline & Бّ & $\begin{array}{l}\text { 息 } \\
\text { 总 } \\
\end{array}$ & & & & 厸 & 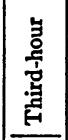 & ङ્ّ & \\
\hline & & & $\begin{array}{l}\text { per } \\
\text { cent }\end{array}$ & per cent & per cent & per & $\begin{array}{c}\text { per } \\
\text { cent } \\
\end{array}$ & $\begin{array}{c}\text { per } \\
\text { cent }\end{array}$ & \\
\hline & Normal & & & & & 70.0 & 20.0 & 90.0 & \\
\hline 1\{ & $\begin{array}{l}180 \\
135\end{array}$ & 9.8 & 4.4 & & 10.0 & 4.3 & 4.9 & 9.2 & Glomerulonephritis; uremia \\
\hline 2 & 118 & $|12.9|$ & 6.3 & & Trace & 5.3 & 1.8 & 7.1 & $\begin{array}{l}\text { Left posterior nephrectomy } \\
\text { right nephrolithiasis }\end{array}$ \\
\hline 3 & 320 & 16.0 & & & $\begin{array}{c}0 \\
\text { Faint } \\
\text { trace }\end{array}$ & 6.9 & 7.4 & 14.4 & $\begin{array}{l}\text { Tuberculosis of ureter, kidney } \\
\text { and bladder }\end{array}$ \\
\hline 4 & 293 & 11.3 & 4.8 & & $\begin{array}{c}\text { Faint } \\
\text { trace }\end{array}$ & 7.6 & 6.4 & 14.0 & Glomerulonephritis; uremia \\
\hline 5 & 161 & 3.2 & & & 30.0 & 13.0 & 14.8 & 27.8 & $\begin{array}{l}\text { Glomerulonephritis; uremia } \\
\text { Exophthalmic goiter }\end{array}$ \\
\hline 6\{ & $\begin{array}{l}90 \\
63\end{array}$ & 4.2 & & & 20.0 & 14.0 & 13.8 & 27.8 & $\begin{array}{l}\text { Arteriosclerosis } \\
\text { Pyelonephrosis }\end{array}$ \\
\hline 7\{ & $\begin{array}{l}96 \\
80\end{array}$ & & & & 50.0 & 20.1 & 14.2 & 34.3 & $\begin{array}{l}\text { Myocardial degeneration; en- } \\
\text { dothelioma of bladder; car- } \\
\text { cinoma of bladder }\end{array}$ \\
\hline 8 & 67 & 6.5 & 3.8 & $\begin{array}{l}1.002- \\
1.010\end{array}$ & 10.0 & 21.7 & 11.0 & 32.7 & Glomerulonephritis \\
\hline 9 & 67 & 4.3 & 5.5 & & 15.0 & 30.0 & 17.2 & 47.2 & $\begin{array}{l}\text { Glomerulonephritis; malignant } \\
\text { hypertension }\end{array}$ \\
\hline 10 & 43 & 1.5 & & 4.6 & $45.0^{*}$ & $* 30.5$ & 25.8 & 56.3 & $\begin{array}{l}\text { Polycystic kidneys; postop- } \\
\text { erative }\end{array}$ \\
\hline 11 & 32 & 1.5 & 3.1 & & 40.0 & 43.3 & 15.5 & 58.8 & $\begin{array}{l}\text { Exophthalmic goiter, general } \\
\text { anasarca; cardiac decom- } \\
\text { pensation }\end{array}$ \\
\hline 12 & 62 & 1.8 & 5.0 & $\begin{array}{l}1.004 \\
1.019\end{array}$ & 55.0 & 43.3 & $\begin{array}{l}17.7 \\
17.8\end{array}$ & 8 & Embolic nephritis \\
\hline 13 & $\begin{array}{l}97 \\
57\end{array}$ & $\begin{array}{l}3.1 \\
1.7\end{array}$ & $\begin{array}{l}5.0 \\
3.4\end{array}$ & $\mid \begin{array}{l}1.001- \\
1.017\end{array}$ & 30.0 & 49.6 & 30.6 & 680.2 & Subacute glomerulonephritis \\
\hline 14 & $\begin{array}{l}78 \\
55\end{array}$ & $\begin{array}{l}1.7 \\
2.1\end{array}$ & 5.7 & & 35.0 & 50.2 & 25.2 & 275.2 & Chronic nephritis \\
\hline 15\{ & $\begin{array}{l}52 \\
22\end{array}$ & $\begin{array}{l}1.6 \\
1.5\end{array}$ & $\left|\begin{array}{r}11.0 \\
4.0\end{array}\right|$ & & 55.0 & 50.5 & 27.4 & 477.9 & Acute glomerulonephritis \\
\hline & & & & & 26.8 & 26.3 & 15.6 & $6|41.9|$ & \\
\hline
\end{tabular}

* Retarded at cystoscopic examination. 
less elevation of the blood urea. In each the benzoate return was definitely low for the two-hour period, which is in contrast to the phenolsulphonephthalein, but roughly parallel to the blood urea. It would seem that, while the patient's general and renal condition had undoubtedly improved, the benzoate test gave the more accurate conception of the degree of residual renal impairment.

Of the patients with nephrosis (table 6) all but one (case 5) showed slight but definite impairment of renal function by the criterion of the benzoate test. In two of these (cases 1 and 2) the benzoate return

TABLE 6

Cases of chronic nephrosis

\begin{tabular}{|c|c|c|c|c|c|c|c|c|}
\hline \multirow[b]{2}{*}{ 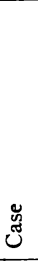 } & \multicolumn{2}{|c|}{$\begin{array}{l}\text { Milligrams for } \\
\text { each } 100 \text { cc. }\end{array}$} & \multirow[b]{2}{*}{ 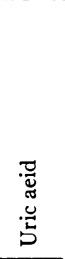 } & \multirow{2}{*}{ 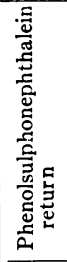 } & \multicolumn{3}{|c|}{$\begin{array}{l}\text { Sodium benzoate } \\
\text { return }\end{array}$} & \multirow[b]{2}{*}{ Diagnosis } \\
\hline & 离 & 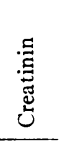 & & & 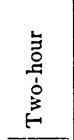 & 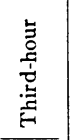 & 胥 & \\
\hline & & & $\begin{array}{l}\text { per } \\
\text { cent }\end{array}$ & $\begin{array}{c}\text { per } \\
\text { cent }\end{array}$ & $\begin{array}{c}\text { per } \\
\text { cent }\end{array}$ & $\begin{array}{l}\text { per } \\
\text { cent }\end{array}$ & $\begin{array}{l}\text { per } \\
\text { cent }\end{array}$ & \\
\hline & Normal & & & & 70.0 & 20.0 & 900 & \\
\hline 1 & 13.0 & 1.1 & 3.7\{ & $\begin{array}{l}45 \\
70\end{array}$ & 59.0 & 20.4 & 79.4 & Nephrosis \\
\hline 2 & 35.2 & 1.9 & 4.6 & $\begin{array}{l}65 \\
80\end{array}$ & 60.8 & 10.2 & 71.0 & Nephrosis \\
\hline 3 & $\begin{array}{l}58.0 \\
19.0\end{array}$ & $\begin{array}{l}2.0 \\
1.5\end{array}$ & 3.8 & 35 & 63.4 & 15.6 & 79.0 & $\begin{array}{l}\text { Anemia; nephrosis (subacute } \\
\text { glomerulonephritis) }\end{array}$ \\
\hline 4 & 22.0 & 1.3 & 2.2 & 65 & 64.6 & 31.9 & 96.5 & Nephrosis \\
\hline 5 & 30.0 & 1.2 & 2.7 & 80 & 70.0 & 11.0 & 81.0 & Nephrosis; tonsil sepsis \\
\hline & p averag & & & 57 & 03.5 & 17.8 & 81.3 & \\
\hline
\end{tabular}

appeared to be relatively more depressed than the phenolsulphonephthalein output and the blood urea would seem to indicate. It appears then that in nephrosis the benzoate output is relatively much higher than in other severe renal lesions, but follows the same general tendency as the urea and phenolsulphonephthalein. Thus it appears that in the human there is a condition analogous to that found by Kingsbury and Bell (23) in the rabbit, that is, that severe injury to the convoluted tubules does not greatly affect the synthesis of hippuric acid. The relatively high benzoate output in these nephroses 
suggests that in the benzoate test we have a further aid in differentiating this type of case in which the damage is mainly tubular (parenchymal), and the type already considered, especially nephritis per se, in which the damage is mainly glomerular.

The recent work of Snapper and Grünbaum (47) may be mentioned in this connection. They administered sodium benzoate in $5 \mathrm{gm}$. doses in cases of various types and compared the elimination after the first 12 hours with that after the second 12 hours. They found that in cases of nephrosis and in those with arteriosclerotic kidneys as well as in normal persons, this doseage was, with the exception of a few hundred milligrams, eliminated quantitatively in the urine within twelve hours, provided there was no urea retention in the serum. In contrast to these cases they found that in similar patients with urea retention the elimination of sodium benzoate might require fortyeight hours, and they questioned whether in such cases there was a delay in the synthesis of hippuric acid or only a delay in its elimination. They inclined toward the latter view because; since hippuric acid is a nitrogenous substance, and since the contracted kidney has diffculty in secreting urine with a high concentration of nitrogenous substances, they believe there must be a close relation between water elimination and hippuric acid elimination. They were able to show that after the administration of sodium benzoate to patients with contracted kidneys, hippuric acid can be demonstrated in the blood in amounts up to $90 \mathrm{mg}$. for each $250 \mathrm{cc}$. of blood, whereas in patients with normal kidneys no hippuric acid, or only spurious traces of it, can be found under like conditions.

Snapper (45) was also successful in demonstrating that within twelve hours human beings with normal kidneys can eliminate hippuric acid that can be synthesized from $5 \mathrm{gm}$. of sodium benzoate, regardless of any other affections. This is found to be true in various types of cancer and various types of cholelithiasis and gastric ulcer, in croupous pneumonia and also in cases with derangements of bile secretion, for instance, patients with cancer of the pancreas with complete icterus. Snapper likewise appreciated the possibility that when glycocolic acid is diverted from the body hippuric acid synthesis might be retarded; this he did not find to be the case. If these conditions cccur with doses as large as $\mathbf{5} \mathbf{g m}$., they certainly should occur 
with a smaller dose of $2.4 \mathrm{gm}$. employed in the sodium benzoate test. Therefore, the work of Snapper et al. tends to strengthen our belief that in this test we have a proper means of estimating the ability of the kidney in synthesizing hippuric acid, and accordingly a reliable index to its general functional capacity.

Group 4. Subjects with only slight renal involvement. The limits of this group were rather indefinite (table 7). These patients had more or less hypertension, more or less arteriosclerosis, more or less myocardial degeneration, but presented normal values of the blood

TABLE 7

Cases of hypertension

\begin{tabular}{|c|c|c|c|c|c|c|c|c|c|c|c|}
\hline \multirow[b]{2}{*}{$\tilde{z}^{\mathscr{z}}$} & \multicolumn{2}{|c|}{$\begin{array}{l}\text { Milligram for } \\
\text { each } 100 \mathrm{cc} \text {. }\end{array}$} & \multirow[b]{2}{*}{ 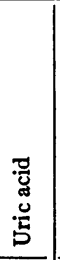 } & \multirow{2}{*}{ 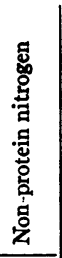 } & \multicolumn{2}{|c|}{$\underset{\text { pressure }}{\text { Blood }}$} & \multirow{2}{*}{ 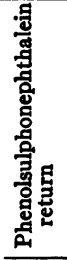 } & \multicolumn{3}{|c|}{$\begin{array}{c}\text { Sodium benzoate } \\
\text { return }\end{array}$} & \multirow[b]{2}{*}{ Diagnosis } \\
\hline & 怘 & 莣 & & & 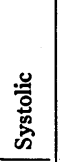 & 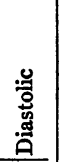 & & 管 & 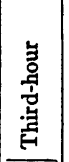 & 胥 & \\
\hline & & & $\begin{array}{l}\text { per } \\
\text { cent }\end{array}$ & $\begin{array}{l}\text { per } \\
\text { cent }\end{array}$ & $\operatorname{mm}_{\boldsymbol{B g}}$ & $\underset{B g}{\operatorname{mm}}$ & $\begin{array}{l}\text { per } \\
\text { cent }\end{array}$ & $\begin{array}{l}\text { per } \\
\text { cent }\end{array}$ & $\begin{array}{c}\text { per } \\
\text { cent }\end{array}$ & $\begin{array}{c}\text { per } \\
\text { cent }\end{array}$ & \\
\hline & Normal & & & & & & & 70.0 & 20.0 & 90.0 & \\
\hline 1 & 21.0 & 1.5 & 5.3 & & 210 & 130 & 45 & 63.2 & 19.4 & 81.5 & $\begin{array}{l}\text { Arteriosclerosis; hyper- } \\
\text { tension; obesity }\end{array}$ \\
\hline 2 & 32.0 & 1.7 & 3.7 & & 220 & 140 & 65 & 68.1 & 19.3 & 87.4 & Malignant hypertension \\
\hline 3 & 34.0 & 1.7 & & 35.0 & 175 & 88 & & 74.9 & 13.6 & 88.5 & $\begin{array}{l}\text { Moderate hypertension; } \\
\text { multiple adenoma; } \\
\text { thyroid }\end{array}$ \\
\hline 4 & 38.0 & 1.4 & 3.2 & & 208 & 113 & 60 & 82.5 & 14.5 & 97.0 & Essential hypertension \\
\hline \multicolumn{11}{|c|}{\begin{tabular}{|l|l|l|l|l|} 
Group average $\ldots \ldots \ldots \ldots \ldots \ldots$ & 57.3 & 72.1 & 16.7 & 88.8
\end{tabular}} & \\
\hline
\end{tabular}

urea and phenolsulphonephthalein return. They had few symptoms pointing to renal disease, and their renal function seemed still to be adequate to their present needs. In such cases there was moderate reduction in the benzoate output, but certainly less than in cases of actual nephritis.

The fact that in cases of this type (table 7, case 1), the benzoate return is reduced before the phenolsulphonephthalein return and blood urea retention, whereas in some of those in the preceding group (table 5, case 15) it is more tardy in returning to normal with improvement in the renal condition, warrants the following suggestion: 
in early cases of renal damage in which the general excretory function of the kidney, as shown by other tests, is good, the evidence points to impaired hippuric acid elimination; later, with progress of the lesion, the major role in the retention is usurped by the inability to synthesize the hippuric acid. This is, of course, of purely academic interest, and the fact apparently remains, that in this test there is an earlier indication of renal impairment than in our present interpretations of phenolsulphonephthalein excretion and blood urea retention.

It is in the border-line cases in this group in which, with advancing life and the gradual impairment of the various systems, a test indicating the "margin of renal safety" would be of greatest value. The desirability of having such a test is evidenced by. the statement of a prominent pathologist (42) that probably 75 per cent of the functioning renal tissue is destroyed before the first clinical signs of renal insufficiency appear. The benzoate test may be more sensitive to these slight changes than other tests employed in this field.

Group 5. Cases with definite hepatic involvement. It was realized that one of the principal objections, physiologically speaking, to the benzoate test of renal function, might be the influence of lowered hepatic function on the synthesis of hippuric acid. In order to determine the extent of this influence tests were made on a number of selected patients with disease of the liver, some of which exhibited not only clinical evidence of organic hepatic disease, but also functional deficiency as indicated by the tetrachlorphthalein and other tests. The degree of this functional impairment, as indicated by the retention of the dye in the blood-stream of these patients is noted in table 10.

All but three of the patients (cases 8, 9, and 10) had a rather definite reduction in the two-hour benzoate output. Five of them (cases 6 , $7,8,9$, and 10) had a three-hour value within 8 per cent of the normal (90 per cent). Even these patients, whose pathologic processes seemed most nearly limited to the liver, seemed to have impairment of the benzoate excretion in the first two hours, but the excretion tended to become more nearly normal in amount during the third hour. These findings are comparable to those of Delprat and Whipple (14), -who noted delay in the output of hippuric acid in dogs with hepatic injury; it also illustrates a tendency, notable throughout this work, of the third-hour value to compensate for the two-hour value, 
TABLE 8

Per cent of free benzoic acid excreted by patients

\begin{tabular}{|c|c|c|c|c|c|c|}
\hline \multirow{2}{*}{ Case } & \multicolumn{3}{|c|}{ Free benzoic acid } & \multicolumn{2}{|c|}{ Difference* } & \multirow{2}{*}{ Diagnosis } \\
\hline & $\begin{array}{l}\text { Two- } \\
\text { hour }\end{array}$ & $\begin{array}{l}\text { Third- } \\
\text { hour }\end{array}$ & Total & $\begin{array}{l}\text { Two- } \\
\text { hour }\end{array}$ & $\begin{array}{l}\text { Third- } \\
\text { hour }\end{array}$ & \\
\hline & per cent & per cent & percent & per cent & per cent & \\
\hline 1 & 0.72 & 1.86 & 2.58 & & & Hypertension; obesity \\
\hline 2 & 0.62 & 0.30 & 0.92 & & & Acute glomerulonephritis \\
\hline 3 & 0.75 & 0.36 & 1.11 & & & Malignant hypertension \\
\hline 4 & 1.20 & 1.05 & 2.25 & & . & Nephrosis \\
\hline 5 & 0.83 & 1.34 & 2.17 & & & Chronic glomerulonephritis \\
\hline 6 & 2.16 & 0.86 & 3.02 & 60.0 & 84.1 & Biliary cirrhosis \\
\hline 7 & 1.05 & 1.24 & 2.29 & & & Chronic nephritis \\
\hline 8 & 1.56 & 1.04 & 2.60 & & & Embolic nephritıs \\
\hline 9 & 1.11 & 0.67 & 1.78 & & & Nephrosis \\
\hline 10 & 0.30 & 0.21 & 0.51 & 3.9 & 8.7 & Chronic glomerulonephritis \\
\hline 11 & 3.23 & 2.87 & 6.10 & 49.2 & 80.7 & Biliary cirrhosis \\
\hline 12 & 3.41 & 2.21 & 5.62 & 48.8 & 65.4 & Common duct stone; obstructive iaundice \\
\hline 13 & 2.87 & 3.36 & 6.23 & 35.9 & 68.8 & Infective jaundice \\
\hline 14 & 0.53 & 0.87 & 1.40 & & & Tuberculosis of the kidneys \\
\hline 15 & 0.86 & 0.69 & 1.55 & & & Carcinoma of the bladder; pyelitis \\
\hline 16 & 1.56 & 1.48 & 3.04 & 82.5 & 91 & Stricture, common bile duct \\
\hline 17 & 1.45 & 1.66 & 3.11 & 25.1 & 35.7 & Obstructive jaundice (postoperative) \\
\hline 18 & 4.10 & 3.80 & 7.90 & 68.1 & 76.7 & Hypertension; gallbladder \\
\hline 19 & 0.69 & 0.57 & 1.26 & 4.6 & 5.8 & Left, nephritis; right, nephrolithiasis \\
\hline 20 & 1.49 & 0.78 & 2.27 & 6.1 & 11.7 & Chronic glomerulonephritis \\
\hline
\end{tabular}

* The difference is between the total and free benzoic acid values, that is, the value for the conjugated, non-toxic hippuric acid expressed as łenzoic acid in percentage terms of the administered dose.

TABLE 9

Comparison of group averages

\begin{tabular}{l|l|c|c|c|c|c}
\hline & \multicolumn{1}{|c|}{ Type } & Cases & $\begin{array}{c}\text { Phenolsulpho- } \\
\text { nephthalein } \\
\text { return }\end{array}$ & & \multicolumn{3}{|c}{ Sodium benzoate return } \\
\cline { 5 - 7 } & & & Two-hour & Third-hour & Total \\
\hline & & & per cent & per cent & per cent & per cent \\
& & & & 70.0 & 20.0 & 90.0 \\
Table 1 & Normal & 13 & 58.2 & 74.7 & 17.3 & 92.0 \\
Table 6 & Hypertension & 4 & 57.3 & 72.1 & 16.7 & 88.8 \\
Table 7 & Nephrosis & 5 & 57.0 & 63.5 & 17.8 & 81.3 \\
Table 12 & Hepatic & 10 & 53.0 & 49.4 & 22.4 & 71.8 \\
Table 5 & Nephritis & 15 & $(3$ cases) & & & \\
\hline
\end{tabular}


thus making the total three-hour value approach normal. This probably indicates a tendency of the synthesis and elimination to proceed at a maximum rate; hence the influence of diet may not be great, as the damaged mechanism can (?) only eliminate so much hippuric acid for each unit of time, regardless of the amount which may have accumulated in the blood stream.

TABLE 10

Degree of functional impairment of liver, and summary of laboratory findings in cases of rather marked hepatic involvement

\begin{tabular}{|c|c|c|c|c|c|c|c|c|c|c|c|}
\hline \multirow{2}{*}{ Case } & \multicolumn{2}{|c|}{$\begin{array}{c}\text { Milli- } \\
\text { grams } \\
\text { for each } \\
100 \mathrm{cc},\end{array}$} & \multirow[b]{3}{*}{ 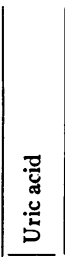 } & \multirow{3}{*}{ 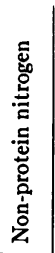 } & \multirow{3}{*}{ 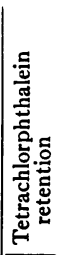 } & \multirow{3}{*}{ 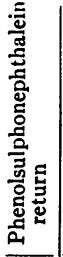 } & \multicolumn{3}{|c|}{$\begin{array}{l}\text { Sodium benzoate } \\
\text { return }\end{array}$} & & \multirow{2}{*}{ Diagnosis } \\
\hline & & & & & & & & & & & \\
\hline & 岕 & 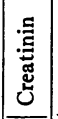 & & & & & 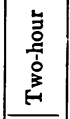 & 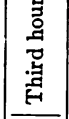 & $\stackrel{\vec{J}}{\circ}$ & "⿺辶卂 & \\
\hline & & & $\begin{array}{l}\text { per } \\
\text { cent }\end{array}$ & $\begin{array}{l}\text { per } \\
\text { cent }\end{array}$ & & $\begin{array}{l}\text { per } \\
\text { cent }\end{array}$ & $\begin{array}{c}\text { per } \\
\text { cent }\end{array}$ & $\begin{array}{c}\text { per } \\
\text { cent }\end{array}$ & $\begin{array}{l}\text { per } \\
\text { cent }\end{array}$ & & \\
\hline Normal & & & & & & & 70.0 & 20.0 & 90.0 & & \\
\hline 1 & 35 & & & 29 & 4 & & 23.4 & 27.1 & 50.5 & 3 & $\begin{array}{l}\text { Toxic jaundice after arsphen- } \\
\text { amine treatment }\end{array}$ \\
\hline 2 & & & & & & & 26.5 & 12.3 & 39.3 & 3 & Obstructive jaundice \\
\hline 3 & 26 & 1.1 & 1.8 & & 4 & & 38.7 & 36.3 & 75.0 & 3 & Jaundice 3 \\
\hline 4 & 28 & & 31 & & 4 & & 26.5 & 24.1 & 30.6 & 4 & Carcinoma of liver? \\
\hline & 15 & 1.4 & 3.1 & & 2 & & 51.2 & 15.5 & 66.7 & 2 & \\
\hline 5 & 36 & & 36.5 & & 4 & & 52.3 & 18.7 & 71.0 & 2 & Obstructive jaundice \\
\hline 6 & 10 & & & & 4 & 40 & 52.4 & 34.4 & 86.7 & 2 & Biliary cirrhosis \\
\hline 7 & 10 & 1.2 & 2.0 & & 3 & 80 & 58.5 & 23.9 & 32.4 & 2 & Cirrhosis \\
\hline 8 & 22 & & & & 4 & & 62.2 & 24.9 & 87.1 & 1 & Cirrhosis \\
\hline 9 & 29 & 1.6 & 1.6 & & 3 & 45 & 64.8 & 20.7 & 85.5 & 1 & Cirrhosis \\
\hline 10 & 12 & 1.4 & 1.7 & & $\begin{array}{l}4 \\
1\end{array}$ & & 84.1 & 9.9 & 94.0 & & $\begin{array}{l}\text { Postoperative stricture of } \\
\text { common duct }\end{array}$ \\
\hline Group a & & & & & & 53 & 49.4 & 22.4 & 71.8 & 2 & \\
\hline
\end{tabular}

* See table 11 .

In order to obtain a basis of comparison in this group between the two tests of greatest significance, the benzoate elimination values for the two-hour period are expressed by grades (see table 11). On this basis table 12 is obtained from table 10 .

In this comparison it appears that in the first four cases there was a somewhat parallel retardation in the elimination of the two sub- 
stances, and in the remainder the lack of parallelism was seemingly the prominent feature, in one (case 8 ) the dye being retained to a marked degree, while the benzoate excretion closely approached normal. In none of these cases was there any notable retention of urea in the blood, which would suggest that the kidneys were functioning normally, and that any impairment in hippuric acid excretion

TABLE 11

\begin{tabular}{c|c}
\hline Grades & Elimination* \\
\hline & per cent \\
1 & $60-70$ \\
2 & $50-60$ \\
3 & $20-50$ \\
4 & Below 20 \\
\hline
\end{tabular}

* Normal elimination is 70 per cent or more.

TABLE 12

Comparison of tetrachlorphthalein and benzoate elimination in ter. cases

\begin{tabular}{c|c|c}
\hline Grade & $\begin{array}{c}\text { Tetrachlorphthalein elimination } \\
\text { grade }\end{array}$ & Benzoate elimination, grade \\
\cline { 2 - 3 } 1 & 4 & 3 \\
2 & - & 3 \\
3 & 2 & 3 \\
4 & 4 & 4 \\
2 \\
5 & 2 & 2 \\
6 & 4 & 2 \\
7 & 4 & 2 \\
8 & 3 & 1 \\
9 & 4 & 1 \\
10 & 3 & 1 \\
\hline Average............ & 1 & 2 \\
\hline
\end{tabular}

was due to other causes, presumably hepatic changes. Before accepting such a hypothesis one must remember that in jaundiced patients, as was notably true for the first four patients in this group, the values for blood urea are decreased (4).

The possibility of hepatic damage limiting hippuric acid synthesis is by no means excluded; in fact, the view is well supported that hepatic damage does delay it. Viewing this group broadly, the 
evidence would seem to demonstrate impairment of renal function rather than hepatic disease per se. Such a view would be in harmony with the work of the recent group studying hepatic function at the Mayo Clinic, especially Counseller, who has histologically demonstrated definite lesions of the nephrosis type in patients who have been suffering from rather protracted obstructive jaundice. With only two of ten three-hour values for benzoic acid in table 10 below 66 per cent, whereas in table 5 only four of fifteen were above it, it appears that in this group there is little evidence of extensive renal damage, even by the criteria of the benzoate test; certainly there is definite contrast between the two groups.

In this connection Snapper's work should be recalled, which showed that patients with complete obstruction of the common duct and those with complete biliary fistula did not differ from those of normal persons in their ability to synthesize and eliminate hippuric acid. However, the twelve-hour test period which he employed would not have revealed any delay in the first two hours as our experiments suggest, as do also those of Delprat and Whipple (14), and of Lachner, Levinson, and Morse (30). Morgulis' (39) suggestion that the liver may play a subsidiary rôle in the synthesis in the mobilization of glycogen is strengthened by our finding a much greater amount of free benzoic acid in this group than in any other.

\section{EXPERIMENTS WITH DOGS}

Dogs were selected whose livers had been subjected to experimental injury of various types. Each received a dose of $0.5 \mathrm{gm}$. of sodium benzoate for each kilogram of body weight, administered intravenously in a 20 per cent solution. Only female dogs were used and specimens of urine were obtained by catheterization two, five, ten, and twenty-four hours after injection of the benzoate. These specimens were examined for total and free benzoic acid by the methods described. In table 13 the benzoic acid return is indicated in terms of the percentage of the administered dose. In the two normal dogs there is similarity not only in the returns for the shorter periods, but in the differences between the total and free benzoic acid values, indicating that the synthesized benzoate or hippuric acid is almost identical, 53.4 and 51.8 per cent. 


\begin{tabular}{|c|c|c|c|c|c|c|c|}
\hline & & 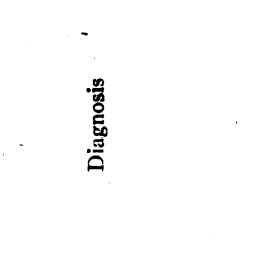 & $\begin{array}{l}\bar{\Xi} \\
\text { है } \\
\text { z }\end{array}$ & 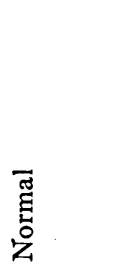 & 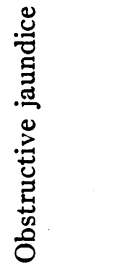 & 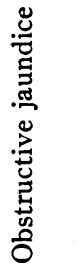 & 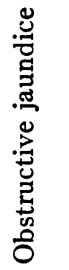 \\
\hline & & {$[870 \mathrm{~L}$} & 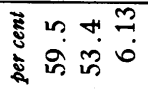 & $\begin{array}{l}\infty \infty 0 \\
\text { in } \frac{0}{0} \text { in }\end{array}$ & 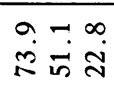 & & $\begin{array}{l}\infty \\
i n\end{array}$ \\
\hline & 壳 & 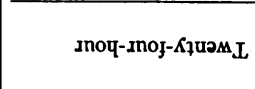 & 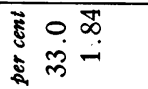 & $\begin{array}{l}0 \hat{\sigma} \\
\infty \\
\dot{m}\end{array}$ & $\begin{array}{ll}\infty & 0 \\
\stackrel{N}{N} & \dddot{v}\end{array}$ & & $\begin{array}{l}\text { ஸे } \\
\text { mं }\end{array}$ \\
\hline & 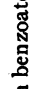 & มก૦Ч-นว & 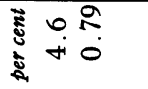 & & $\ddot{\infty} \dot{a}$ & & $\stackrel{\sim}{\sim} n$ \\
\hline 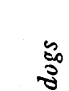 & 总 & 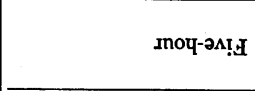 & 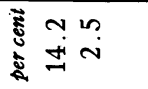 & $\because 9$ & $\begin{array}{l}0 ? \\
\because 0\end{array}$ & $\ddot{\ddot{r}}$ & $\stackrel{\sim}{\infty}$ \\
\hline $\begin{array}{c}\frac{9}{2} \\
\frac{5}{2}\end{array}$ & & $\operatorname{moY}^{-O M} \mathrm{~L}$ & 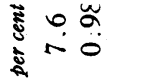 & $\ddot{a} \dot{0}$ & $\begin{array}{ll}\infty & 0 \\
\sim & 0\end{array}$ & in & in \\
\hline$=\overrightarrow{\vec{z}}$ & & 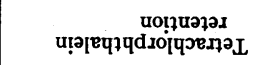 & 0 & & $H$ & & $\sim$ \\
\hline 范 & . & 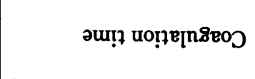 & 逽 & & N & & in \\
\hline $\begin{array}{l}3 \\
\text { 3े } \\
\text { ? }\end{array}$ & 总 & 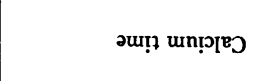 & 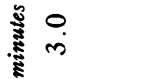 & & $\because$ & & $\stackrel{0}{\text { in }}$ \\
\hline$\tilde{n}$ & & 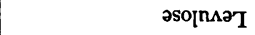 & 0 & & & & \\
\hline & & u!qnג!!!!g & 0 & & & & \\
\hline & & 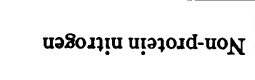 & 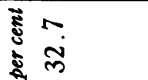 & & $\stackrel{\sim}{\infty}$ & & in \\
\hline & . & с вәл & 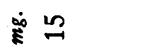 & & 은 & & in \\
\hline & 鸪 & 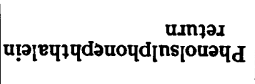 & है & & 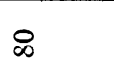 & & 유 \\
\hline & & uəunqly & $\rightarrow$ & & $\sim$ & & - \\
\hline & & $\ddot{0}$ & $\stackrel{\bar{N}}{-}$ & $\ddot{\varkappa} N$ & 岁m & $\frac{\stackrel{+}{T}}{\stackrel{N}{N}}$ & 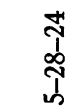 \\
\hline
\end{tabular}




\begin{tabular}{|c|c|c|c|c|}
\hline 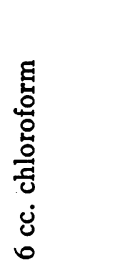 & 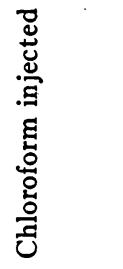 & 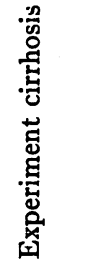 & 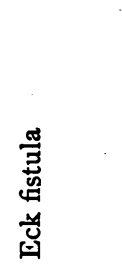 & 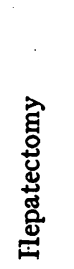 \\
\hline & $\frac{0}{a}$ & 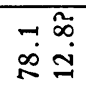 & 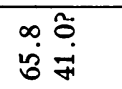 & \\
\hline & $\hat{\infty} \sim$ & 常 & 艄 & \\
\hline & $\overrightarrow{\tilde{N}} \ddot{F} \vec{i}$ & & & \\
\hline & 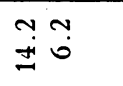 & 我 & $\tilde{0}$ & \\
\hline & 苂 & $\ddot{m}^{n}$ & $\ddot{m} \underset{-i}{n}$ & mi \\
\hline 0 & $r$ & $m$ & & \\
\hline in & 0 & in & & \\
\hline in & $\stackrel{n}{\infty}$ & $\ddot{+}$ & & \\
\hline 0 & 0 & & & \\
\hline 0 & & & & \\
\hline ஸ̆ & & ஜृ. & & \\
\hline ఉ゙ & F & 오 & & \\
\hline & & 8 & & \\
\hline 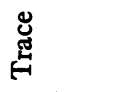 & N & $\rightarrow$ & & \\
\hline 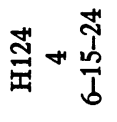 & $\frac{\mathbb{T}}{\frac{1}{1}}$ & 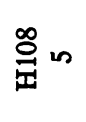 & 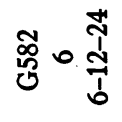 & $\frac{\stackrel{7}{7}}{\frac{1}{b}}$ \\
\hline
\end{tabular}


Dog 3 with definite, severe, and progressive obstructive jaundice was given benzoate on three occasions. The phenol-tetrachlorphthalein and bilirubin tests indicated definite hepatic injury. The values for the benzoate determinations, however, were, at the time of the first examination, very nearly parallel to those of the normal dogs, the difference being $\mathbf{5 1 . 1}$ per cent; the values for the shorter periods did not vary more than the corresponding ones might for normal dogs. Later examinations showed no significant ćhange from the first examination. Here then, despite a progressive hepatic lesion the benzoate values were essentially normal, as were the renal function tests.

Dog 4 had normal renal function, normal phenol-tetrachlor-phthalein return, normal coagulation time, and no serum bilirubin. The following day $6 \mathrm{cc}$. of chloroform in oil was given intramuscularly. A day later there was bilirubin in the serum, an increased coagulation time, and marked retention (grade 3) of phenol-tetrachlor-phthalein: these results all point to definite acute impairment of hepatic function. In this case the amount of synthesized benzoate at the end of two hours was 16 per cent, and at the end of ten hours 41.6 per cent, values essentially equivalent (?) to those found in the normal dogs.

Dog 5 had six intra-portal injections of chloroform; at operation just preceding the injection of benzoate the liver was seen to be shrunken and distorted by bands of fibrous tissue. The liver function tests showed considerable serum bilirubin and notable (grade 3) retention of phenol-tetrachlor-phthalein; the renal function, on the other hand, was normal as shown by the phenol-sulphone-phthalein test $(60$ per cent). Despite the hepatic injury the synthesized benzoate values appear quite normal, 65.3 per cent being synthesized during the twenty-four hours following the administration of the benzoate, and the values for the shorter periods were quite comparable to those found in normal dogs.

Dog 6, when first examined, had an Eck fistula, made preparatory to hepatectomy; while no functional tests had been made it is known that the hepatic function in such cases is somewhat impaired. The values following the first benzoate administration were essentially normal. Somewhat later this dog was hepatectomized by Mann (37) by his own method, but unfortunately the dog became anuric 
after the collection of the two-hour specimen. This specimen showed a definite synthesis of hippuric acid although the amount was smaller than on the previous examination. This may have been due to the factors causing the anuria, such as fall in blood pressure or surgical shock, rather than to failure of the detoxicating mechanism itself. The absence of the liver may have been responsible for the anuria, since with the failure of glycocoll mobilization, which we conceive as the hepatic rôle in this synthesis, the rather large dose of sodium benzoate became actually toxic. It would be interesting to know whether synthesis might not have taken place essentially as well in 'such a dog as in others had glycocoll been given intravenously following the hepatectomy.

This work on dogs strongly supports the belief that in the dog the liver has no direct concern in the detoxication of hippuric acid, but that it is probably essential to mobilization of the glycocoll necessary to the synthesis. This work seems in harmony with the results noted in human patients, although it is not directly comparable since in the dog benzoic acid is not normally conjugated to hippuric acid to as large an extent as in the human.

FREE BENZOIC ACID

Morgulis and his co-workers objected to the benzoate test as proposed by Kingsbury on the basis of inaccuracies due to the fact that a certain amount of benzoic acid is excreted in the free state. In table 8 our findings in this regard are abstracted. Two-hour and three-hour values for free benzoic acid were obtained in twenty of the cases (table 8). The per cent of free benzoic acid, relative to the administered dose, is indicated, and the values are therefore comparable to those of the total benzoic acid eliminated. The results may be summarized as follows: two cases, 0 to 1 per cent; five cases, 1 to 2 per cent; six cases, 2 to 3 per cent; and seven cases, more than 3 per cent.

It is significant that all of the patients with values above 3 per cent had hepatic impairment; of these, two had biliary cirrhosis, and two obstructive jaundice; one was a case of infectious jaundice, one had a stricture of the common bile duct, and the last had cholecystitis. 
This evidence gives weight to the hypothesis of Morgulis that the rôle of the liver in this particular function is secondary only and is mainly concerned with the formation or mobilization of glycocoll. Such an hypothesis would lead one to suppose that there is, at a given time, insufficient glycocoll in the blood stream for a maximal detoxication by the kidneys, which, being intact, detoxicate and eliminate the benzoic acid as fast as the requisite glycocoll is brought to them. This would be in harmony with the situation described in this section of our work, with the delay observed by Delprat and Whipple, and by Lachner, Levinson, and Morse, with the increased formation of hippuric acid with increased glycocoll feeding as described by such workers as Lewinski, Griffith and Lewis, and Csonka, and with the delay in hippuric acid elimination observed by us in hepatic cases during the first two-hour period of the test, tending to attain by the end of the third hour a normal full three-hour value. In the hepatic cases there appeared to be a faulty synthesis rather than the faulty elimination observed in the severe nephritic cases.

The error of this test as an indicator of renal function is probably greatest in cases with hepatic disturbance; in such cases the threehour total value is most significant from a renal standpoint. From our data it appears that a three-hour free-benzoic acid value which is above 3 per cent after giving $2.4 \mathrm{gm}$. of sodium benzoate is highly suggestive of some hepatic disturbance. On the other hand, from table 8 it appears that even in cases of marked renal insufficiency (cases 10,19, and 20) much smaller amounts of free benzoic acid are excreted in the urine and at no time were these great enough to detract from the clinical information available from the test.

\section{DISCUSSION}

Since the main points indicated by the examination of the various groups were discussed in their appropriate relations, little in the nature of a general discussion is necessary. A few points will, however, be emphasized.

The synthesis of hippuric acid is not seriously interfered with by diseases of the parenchyma of the kidney, as severe nehprosis. In destructive lesions of the kidney, such as those due to tumors, multiple 
cysts, tuberculosis, or nephritis, there is marked interference with its elimination. Although, according to the work of Snapper, it appears that even here the hippuric acid may be synthesized and merely dammed back in the blood stream, this seems to us decidedly open to doubt in the severest cases.

The two-hour value, from a renal standpoint, is probably the more significant figure of the test for reasons heretofore elaborated. In this connection a suggestion might be offered for the use of the benzoate test in conjunction with the phenol-sulphone-phthalein test. The diet had best be controlled with regard to fruits, especially cranberries, for from twelve to twenty-four hours preceding the test. Immediately after voiding the morning specimen, the usual amount of phenol-sulphone-phthalein should be given intravenously. Fifteen minutes later the patient should take $2.4 \mathrm{gm}$. of sodium benzoate as described. The urine for two hours and fifteen minutes should be collected as a single specimen, carefully measured, and several portions taken for the determination of the phenol-sulphone-phthalein and total benzoic acid values.

\section{CONCLUSIONS}

1. The sodium benzoate test is of value in determining the functional capacity of the kidneys. No other type of affection so definitely and markedly affects its synthesis or elimination. However, a free benzoic acid value above 3 per cent of the administered dose of sodium benzoate suggests a secondary hepatic lesion, the high value probably being due to the inability of the liver to mobilize glycocoll; it probably should not be construed as reflecting against the ability of the kidney to detoxicate the substance. In other cases the amount of free benzoic acid is probably negligible, clinically speaking.

2. The benzoate test is probably a more delicate indicator of early functional renal disturbance than other tests in common use, and, therefore, should be of greatest value in patients with early suspected renal involvement, or in patients whose phenol-suphone-phthalein or blood urea tests are still normal or have returned to normal. The test has no particular advantage over other tests in advanced cases, inasmuch as the technique is more time consuming, although this 
factor, in a well organized laboratory in an institution where many renal cases are studied is by no means prohibitive.

3. The results of these experiments confirm those of Kingsbury regarding the standard of "normal" excretion for this test, which is an excretion of 70 per cent or more of the benzoic acid equivalent of the sodium benzoate in two hours, and from 85 to 90 per cent or more, in three hours.

4. The work on dogs gave little evidence that the ability of the animal to synthesize and eliminate hippuric acid was decreased when the liver was damaged or absent, except that there was a lack of available glycocoll, making the synthesis impossible for other organs, such as the kidney.

5. Further work might demonstrate the determination of free benzoic acid elimination, after administration of a standard dose of sodium benzoate, to be of value as a functional test in establishing the degree of hepatic impairment.

\section{BIBLIOGRAPHY}

1. Abderhalden, E., and Hirsch, P.: Ztschr. f. physiol. Chem., 1912, lxxviii, 292-305. Die Bildung von Glykokoll in tierischen Organismus.

2. Bashford, E., and Cramer, W.: Ztschr. f. physiol. Chem., 1902, xxxv, 324-326. Ueber die Synthese der Hippursäure im Thierkörper.

3. Baumann, E.: Ztschr. f. physiol. Chem., 1886, x, 123-133. Die aromatischen Verbingungen im Harn und die Darmfäulniss.

4. Bollman, J. C., Mann, F. C., and Magath, T. B.: Amer. Jour. Physiol., 1924, lxix, 371-393. Studies on the Physiology of the Liver. VIII. Effect of Total Removal of the Liver on the Formation of Urea.

5. Brakefield, J. L., and Schmidt, C. L. A.: Proc. Soc. Exper. Biol. and Med., 1904, xxi, 206. The Synthesis of Hippuric Acid by Jaundiced Animals.

6. Brugsch, T.: Ztschr f. exper. Path. u. Therap., 1909, v, 733-737. Ueber die Grenzen der Hippursäurebilding beim Menschen.

7. Brugsch, T., and Hirsch, R.: Ztschr. f. Exper. Path. u. Therap., 1906, iii, 663-674. Hippursäuresynthese und Auscheidung der Benzoësäure beim Hunde.

8. Bunge, G., and Schmiedeberg, O.: Arch. f. exper. Path. u. Pharmakol., 1877, vi, 233-255. Ueber die Bildung der Hippursäure.

9. Cohn, R.: Festschrift f. M. Jaffe, Braunschweig, 1901, p. 313. Ueber den Glykokollvorrat des thierischen Organismus.

10. Cohn, R.: Arch. f. exper. Path. u. Pharmakol., 1902, xlviii, 177-183. Zur Frage der Glykokollbildung aus Leucin im thierschen Organismus. 
11. Csonka, F. A.: Jour. Biol. Chem., 1924, 1x, 545-582. Animal Colorimetry. On the Administration of Various Proteins with Benzoic Acid to a Pig.

12. Csonka, F. A.: Proc. Soc. Exper. Biol. and Med., 1924, xxi, 169-170. Varieties of Protein as Factors in Hippuric Acid Production.

13. Dakin, H. D.: Jour. Biol. Chem., 1909-1910, vii, 103-108. The fate of Sodium Benzoate in the Human Organism.

14. Delprat, G. D., and Whipple, G. H.: Jour. Biol. Chem., 1921, xlix, 229-246. Benzoate Administration and Hippuric Acid Synthesis.

15. Du Bois, D., and Du Bois, E. F.: Arch. Int. Med., 1916, xvii, 863-871. Clinical Colorimetry. X. A Formula to Estimate the Approximate Surface Area if Height and Weight Be Known.

16. Epstein, A. A., and Bookman, S.: Jour. Biol. Chem., 1911-1912, x, 353-371. Studies on the Formation of Glycocoll in the Body. I.

17. Friedmann, H., and Tachau, H.: Biochem. Ztschr., 1911, xxxv, 88-103. Ueber die Bildung des Glykokolls im Thierkörper. I. Synthese der Hippursäure in der Kanninchenleber.

18. Fürth, O. V.: Philadelphia, 1916, 107-112. The problems of the Physiological and Pathological Chemistry of Metabolism.

19. Griffith, W. H., and Lewis, H. B.: Jour. Biol. Chem., 1923, lvii, 697-707. VI. The Influence of the Protein of the Diet on the Synthesis and Rate of Elimination of Hippuric Acid after the Administration of Benzoates.

20. Griffith, W. H., and Lewis, H. B.: Jour. Biol. Chem., 1923, lvii, 1-24. V. The Influence of Amino-acids and Related Substances on the Synthesis and Rate of Elimination of Hippuric Acid after the Administration of Benzoate.

21. Hoffmann, A.: Arch. f. exper. Path. u. Pharmakol., 1877, vii, 233-246. Ueber die Hippursäurebildung in der Niere.

22. Jaarsveld, G. J., and Stokvis, B. J.: Arch. f. exper. Path. u. Pharmakol., 1879, x, 268-300. Ueber den Einfluss von Nierenaffectionen auf die Bildung von Hippursäure.

23. Kingsbury, F. B., and Bell, E. T.: Jour. Biol. Chem., 1915, xx, 73-82. The Synthesis of Hippuric Acid in Experimental Tartrate Nephritis in the Rabbit.

24. Kingsbury, F. B., and Bell, E. T.: Jour. Biol. Chem., 1915, xxi, 297-301. The Synthesis of Hippuric Acid in Nephrectomized Dogs.

25. Kingsbury, F. B., and Swanson, W. W.: Arch. Int. Med., 1921, xxviii, 220-236. The Synthesis and Elimination of Hippuric Acid in Nephritis: a New Renal Function Test.

26. Kingsbury, F. B., and Swanson, W. W.: Jour. Biol. Chem., 1921, xlviii, 13-20. A Rapid Method for the Determination of Hippuric Acid in Urine.

27. Kochs, W.: Pflüger's Arch., 1879, xx, 64-80. Ueber eine Methode zur Bestimmung der Topographie des Chemismus im thierschen Körper.

28. Kronecker, F.: Arch. f. exper. Path. u. Pharmakol., 1883, xvi, 344-360. Ueber die Hippursäurebildung beim Menschen im Krankheiten. 
29. Kühne, W., and Hallwachs, W.: Virchow's Arch. f. path. Anat., 1857, xii, 386-396. Ueber die Entstehung der Hippursäure nach dem Genusse von Benzoësäure.

30. Lackner, E., Levinson, A., and Morse, W.: Jour. Biol. Chem., 1918, xxxiii, xvi-xviii. Aspects of Hippuric Acid Conjugation.

31. Lewinski, J.: Arch. f. exper. Path. u. Pharmakol., 1908, lviii, 397-412. Ueber die Grenzen der Hippursäurebildung beim Menschen.

32. Lewis, H. B.: Jour. Biol. Chem., 1921, xlvi, 73-75. Studies on the Synthesis of Hippuric Acid in the Animal Organism. IV. A Note on the Synthesis of Hippuric Acid in the Rabbit after the Exclusion of Bile from the Intestine.

33. Lewis, H. B.: Jour. Biol. Chem., 1914, xviii, 225-231. II. The Synthesis and Rate of Elimination of Hippuric Acid after Benzoate Ingestion in Man.

34. Lewis, H. B., and Karr, W. G.: Jour. Biol. Chem., 1916, xxv, 13-20. III. The Excretion of Uric Acid in Man after Ingestion of Sodium Benzoate.

35. McCollum, E. V., and Hoagland, D. R.: Jour. Biol. Chem., 1913-1914, xvi, 321-225. III. The Influence of Benzoic Acid on the Endogenous Nitrogen Metabolism.

36. Magnus-Levy, A.: Biochem. Ztschr., 1907, vi, 523-540. Ueber die Neubildung von Glykokoll.

37. Mann, F. C.: Amer. Jour. Med. Sc., 1921, clxi, 37-42. Studies in the physiology of the liver. I. Technic and general effects of removal.

38. Mathews, A. P.: Physiological chemistry. New York, 3rd. ed., 1920, 740.

39. Morgulis, S., Pratt, G. P., and Jahr, H. M.: Arch. Int. Med., 1923, xxxi, 116-144. Hippuric Acid Synthesis as a Test of Renal Function.

40. Report of the "Remsen Board." Washington Government Printing Office, 1909. Report No. 88. Influence of Sodium Benzoate on the Health of Man. United States Department of Agriculture.

41. Ringer, A. I.: Jour. Biol. Chem., 1911-1912, x, 327-338. On the Maximal Production of Hippuric Acid in Animals with Consideration of the Origin of Glycocoll in the Animal Body.

42. Robertson, H. E.: Personal communication, 1924.

43. Rosenberg, S.: Zentralbl. f. inn. Med., 1901, xxii, 696-698. Ueber die Beziehungen zwischen Galle und Hippursäurebildung im thierischen Organismus.

44. Schmiedeberg, O.: Arch. f. exper. Path. u. Pharmakol., 1881, xiv, 379-392. Ueber Spaltungen und Synthesen im Tierkörper.

45. Snapper, I.: Klin. Wchnschr., 1924, iii, 55-56. Der Hippursäure-Stoffwechsel beim Menschen.

46. Snapper, I., and Laqueur, E.: Biochem. Ztschr., 1924, cxlv, 32-39. Bestimmung der Hippursäure im Harn.

47. Snapper, I., and Grünbaum, A.: Klin. Wchnschr., 1924, iii, 101-104. Der Hippursäure-Stoffwechsel bei Nierenkrankheiten. 
48. Snapper, I., Grünbaum, A., and Neuberg, J.: Biochem. Ztschr., 1924, cxlv, 40-46. Ueber die Hippursäuresynthese in der überlebenden Niere von verschiedenen Tiergattungen, auch von Menschen.

49. Violle, P. L.: Ann. de méd., 1920, vii, 272-279. De l'élimination de l'acide hippurique a l'état normal et pathologique.

50. Weyl, T., and Anrep, B. v.: Ztschr. f. physiol. Chem., 1880, iv, 169-189. Ueber des Ausscheidung der Hippursäure und Benzoësäure während des Fiebers.

51. Wiechowski, W.: Hofmeister's Beitr., 1906, vii, 204-275. Die Gesetze der Hippursäuresynthese (Zugleich ein Beitrag zur Frage der Stellung des Glykokolls im Stoffwechsel).

52. Wiener, H.: Arch. f. exper. Path. u. Pharmakol., 1898, xl, 313-325. Ueber das Glykokoll als intermediäres Stoffwechselproduct. 